\title{
LUPU, TUTTLE, AND SINGLING OUT RELIGION
}

\author{
Andrew Koppelman ${ }^{*}$
}

\section{Review of Ira C. Lupu \& Robert W. Tuttle's SECULAR GOVERNMENT, RELIGIOUS PEOPLE (2014).}

Ira C. Lupu and Robert W. Tuttle's Secular Government, Religious People $^{1}$ is one of the very best overviews of the American law of religious liberty in print. It is an excellent introduction to the subject, and it makes sense of some tangled areas of doctrine in ways that will enlighten specialists. Their knowledge of the law is encyclopedic, and they deliver it with astonishing compression and grace. The chapter on government funding of religion, which sympathetically reconstructs the rationale of the now abandoned rule against any funding of religion while exposing its limitations, is particularly impressive. ${ }^{2}$

Lupu and Tuttle's fundamental claim is that religious liberty in America is founded on a jurisdictional limit upon government competence. ${ }^{3}$ Government is fundamentally secular: "the nonestablishment principle defines a government that receives its authority from the people, not from revealed or transcendent sources, and that recognizes the limited scope of its authority over the people." 4 They work out the implications of this principle for both government endorsement of religious propositions and exemption from generally applicable laws.

A keystone of the book's argument is its response to an increasingly salient question: what makes religion special $?^{5}$ That response has important implications for religious accommodation. This brief Review will focus on those issues.

Lupu and Tuttle note but dismiss two prominent answers to the question of why religion is special, which they call the "authentic choice" and "civil peace" approaches. ${ }^{6}$ The first holds that "religion is special because of its constitutive role in human identity and well-being." The

\footnotetext{
* John Paul Stevens Professor of Law and Professor of Political Science, Department of Philosophy Affiliated Faculty, Northwestern University. These remarks were originally delivered at a symposium in honor of Ira C. Lupu \& Robert W. Tuttle's Secular Government, Religious People at the Annual Law and Religion Roundtable, Georgetown University Law Center, June 25, 2015.

${ }^{1}$ Ira C. Lupu \& Robert W. Tuttle, Secular Government, Religious People (2014).

2 Id. at $74-112$

${ }^{3} I d$. at 4 .

${ }^{4} I d$. at 5 .

${ }^{5}$ Id.

${ }^{6} I d$. at 23 .

7 LUPU \& TUTTLE, supra note 1 , at 22.
} 
second, which arises out of the experience of religious wars, aims to avoid destructive conflict. ${ }^{8}$ Both have played a role in shaping doctrine, "[b]ut neither approach offers a fully convincing explanation of why the concept of nonestablishment should treat religion as distinctive." Nonreligious commitments can also play a constitutive role in personal identity, and nonreligious conflicts can also be a threat to order. ${ }^{10}$

Instead, they regard religion as an attribute of political authority:

From this perspective, three characteristics of religion present the problem to which nonestablishment responds. First, religion locates the source of its authority in a transcendent and eternal being or order, to which all temporal beings and orders are subject. Second, religion asserts comprehensive jurisdiction; its competence and authority extend to all dimensions of human life. And third, the subjects of religious authority respond to it by worship and submission. ${ }^{11}$

"Nonestablishment," they write, "marks a radical break with previous links between government and all three characteristics of religion." 12

This radical break obviously limits the state's capacity to claim transcendent authority, or to decide religious questions. It demands that laws have secular purposes.

All this makes sense. But, strangely, Lupu and Tuttle say very little about what motivates the "radical break" they describe. Why are the three characteristics of religion so bad, from a political perspective? Some of their formulations suggest that the underlying aim is to prevent the abuse of government power: "The relationship between government and people is not one of master and servant, but quite the reverse."13 But established religion can be democratically accountable. The people can vote on which religious propositions the state is going to embrace. The Establishment Clause presents the same countermajoritarian difficulty as the rest of constitutional law. One of the most striking effects of allowing legislative prayer has been that elections have been fought on precisely this basis. ${ }^{14}$

The missing element of disestablishment, one that gets no discussion in Lupu and Tuttle, although it had a powerful influence on the Framers and on the modern Supreme Court, is the idea that religion can be corrupted and degraded by state support. ${ }^{15}$ If you think, as James Madison

8 Id. at $22-23$.

9 Id. at 24 .

${ }^{10}$ Id. at $24-25$.

11 Id. at 25.

12 Id. at 26.

${ }^{13}$ LuPU \& TUTTLE, supra note 1, at 29.

${ }^{14}$ See Christopher C. Lund, Legislative Prayer and the Secret Costs of Religious Endorsements, 94 MinN. L. REV. 972 (2010) [https://perma.cc/XTG7-B93B].

15 See Andrew Koppelman, Corruption of Religion and the Establishment Clause, 50 WM. \& MARY L. REV. 1831 (2009) [https://perma.cc/BM4E-RTAH]; Andrew Koppelman, Justice Stevens, Religious Enthusiast, 106 NW. U. L. REV. 567 (2012) [https://perma.cc/54AN-77XK]. 
and the Warren Court did, that "religion is too personal, too sacred, too holy, to permit its "unhallowed perversion' by a civil magistrate," 16 then you will embrace the radical break that Lupu and Tuttle describe.

There is a growing scholarly consensus (I'm a dissenter) that special treatment of religion cannot be justified. With respect to free exercise, some think there should never (or almost never) be accommodation, ${ }^{17}$ while others think that accommodation is appropriate, but under a different description; that it is morally arbitrary and unfair to single out religion for special treatment. ${ }^{18}$ Disestablishment, too, should not single out religion. Rather, government should be prohibited from endorsing any comprehensive view or conception of the good. ${ }^{19}$

Lupu and Tuttle do not respond to these views. In part that is a consequence of their strategic decision to focus on the Supreme Court and ignore most of the scholarly debates. But the Court, too, is uneasy and inarticulate about the reasons for singling out religion. The operational meaning of the First Amendment is likely to be different depending on what underlying purposes are attributed to the Amendment.

Lupu and Tuttle implicitly rely on the undefended premise that government should not make pronouncements on religious doctrine. (That premise would make sense in light of the corruption rationale.) This reliance is clearest in their attack on the rule of Sherbert $v$. Verner ${ }^{20}$ and the Religious Freedom Restoration Act of 1993, that "Government shall not substantially burden a person's exercise of religion even if the burden results from a rule of general applicability," unless the Government "demonstrates that application of the burden to the person-(1) is in furtherance of a compelling governmental interest; and (2) is the least restrictive means of furthering that compelling governmental interest." ${ }^{21}$

This rule, they argue, "raises profound questions about (1) the legitimacy of privileging religiously motivated conduct over its secular analogues, and (2) the state's competence to decide the significance of burdens on religiously motivated behavior." ${ }^{22}$ Religion should be protected, they argue, but under the description of nonreligious rights, such as freedom of speech and association. ${ }^{23}$ This approach "makes religionists and

\footnotetext{
16 Engel v. Vitale, 370 U.S. 421, 431-32 (1962) (quoting JAMES MADISON, MEMORIAL AND REMONSTRANCE AGAINST THE GENERAL ASSESSMENT (1785)) [https://perma.cc/XL3U-9ZPQ].

${ }^{17}$ See, e.g., Brian Barry, Culture and Equality: AN Egalitarian Critique of Multiculturalism (2001).

18 See Andrew Koppelman, Defending American Religious Neutrality 120-65 (2013) and sources cited therein.

${ }^{19}$ See, e.g., Micah Schwartzman, What If Religion Is Not Special?, 79 U. CHI. L. REV. 1351, $1423-$ 24 (2012) [https://perma.cc/QN9G-F3BQ].

20374 U.S. 398 (1963) [https://perma.cc/XY8X-KRUQ].

2142 U.S.C. $\$ \S 2000 \mathrm{bb}-1$ (a), (b) [https://perma.cc/L6A7-UG3A]

22 LUPU \& TUTTLE, supra note 1, at 192.

${ }^{23} \mathrm{Id}$. at 180 . Occasionally they provide too optimistic an account of these other rights. For instance, they argue that the principle of neutrality among religions was betrayed by the campaign
} 
secularists into partners in developing a workable theory of the limited state." ${ }^{24}$ They boldly try to rehabilitate the notion of "hybrid" rights, one of the most incoherent aspects of the Employment Division v. Smith ${ }^{25}$ decision, by construing it as "a reference to situations in which religious freedom is subsumed in other, more general rights." 26

Yet Lupu and Tuttle are oddly ambivalent. On a single page, they denounce "exemptions from general laws regulating the conduct of all," 27 but then they accept a 1793 decision allowing Jews to decline to testify on a Saturday, because "disputes about the relationship between religious conviction and the calendar ... do not involve basic norms of right versus wrong behavior." 28 So not all "general laws regulating the conduct of all" involve "basic norms of right versus wrong behavior." 29

They declare that their opposition to religion-specific accommodation is not "limited to the judicial branch," but "attaches to all branches and all levels of government." 30 Yet they accept exemptions for "certain religious groups from rules of road safety or restrictions on the use of controlled substances," because "[i]n such situations, the state simply moves out of the way and allows the religiously motivated practice to proceed." ${ }^{31}$ But these accommodations are, what was rejected elsewhere, "exemptions from general laws regulating the conduct of all." 32

A ban on legislative accommodation, they argue, would be unfair: "Because nonreligious practices or groups can seek specific forms of responsiveness in their favor, a categorical ban on relief that is targeted to religion would effectively and unjustifiably disfavor religion." ${ }^{33}$ But they also argue that analogies are very hard to evaluate. The possibility of skin irritation from shaving is not really comparable to the cost of defying God's will, and exemption for sacramental wine during Prohibition is not

\footnotetext{
against Mormons in the late nineteenth century. They assert that Davis v. Beason, 133 U.S. 333 (1890) [https://perma.cc/Q9EN-ANFW], which denied the vote to anyone belonging to an organization that counsels polygamy, "permitted the territory to condition one basic right-participation in the democratic process - on surrender of others, including the right to belong to a particular religious community." LUPU \& TUTTLE, supra note 1, at 182 . Their citation of late nineteenth century freedom of association cases is anachronistic, however. The law of that time is better reflected by such guilt-byassociation cases as Gitlow v. New York, 268 U.S. 652 (1925) [https://perma.cc/9JZJ-D8CG].

${ }^{24}$ LUPU \& TUTTLE, supra note 1, at 180.

25494 U.S. 872, 882 (1990) [https://perma.cc/9UCP-5AFQ].

${ }^{26}$ LUPU \& TUTTLE, supra note 1, at 187 n.33.

${ }^{27} I d$. at 181 .

28 Id. at 181 n.7 (citing Stansbury v. Marks, 2 Dall. 213 (Pa. 1793) (discharging a fine brought against Jewish witness who refused to testify on a Saturday) [https://perma.cc/G5Z4-VE7X]).

${ }^{29}$ Id.

${ }^{30} I d$. at 201.

${ }^{31} I d$. at 212 (footnotes omitted).

32 LUPU \& TUTTLE, supra note 1, at 181.

${ }^{33} I d$. at 216.
} 
necessarily analogous to Native American use of hallucinogens. ${ }^{34}$ It is hard to be confident that there is any unfairness.

Lupu and Tuttle's real objection thus appears to be, not to the practice of religious accommodation, but to the attempt to codify that practice into a rule. Legislative accommodation predates the framing of the Constitution, but the principle of religious accommodation "had never before appeared in our constitutional law" ${ }^{35}$ before Sherbert ${ }^{36}$ in 1963. It is the codification that demands that courts assess burdens on religion, which in turn demands evaluation of the centrality of any practice to a religion. However, "secular government lacks the jurisdictional competence to determine the religious significance - the substantiality — of the alleged burden." ${ }^{37}$ Again, this argument would be stronger if they provided a clearer account of the basis for this jurisdictional boundary.

Maybe Lupu and Tuttle are right that the rule will not work. It is still too early to tell. The Court limited it in all sorts of unprincipled ways between Sherbert and Smith. ${ }^{38}$ More recently, in Burwell v. Hobby Lobby Stores, Inc. ${ }^{39}$ the Court lurched far in the other direction, suggesting that it may even be permissible for a religious group to impose serious harms on discrete, identifiable nonadherents if courts can imagine some hypothetical, albeit politically impossible, less restrictive means for achieving the state's purpose. ${ }^{40}$

It is probably possible to do a better job of implementing an exemption rule than the Court has done. But the core problem Lupu and Tuttle identify persists: when a burden on religion is claimed, the state's lawyer inevitably will argue "that a particular religious practice is trivial, or nonobligatory, or capable of being replaced by a substitute practice." ${ }^{41}$

The problem is a tough one..$^{42}$ Kent Greenawalt's exhaustive survey of the case law concludes that the best judges can hope to do is to "reasonably comprehend a person's religious beliefs and practices" and thereby to "be able to identify some interferences as very great and others as trivial." ${ }^{\prime \prime 3}$ His

\footnotetext{
34 Id. at 209

35 Id. at 192 ("Sherbert ... stands for the principle that general laws might violate the Free Exercise Clause when they impose burdens on people who have religious motivations for not complying with those laws.").

36374 U.S. 398 (1963).

37 LUPU \& TUTTLE, supra note 1, at 197.

38 See id. at 194-95 (discussing the Supreme Court's "campaign to create increasingly forceful and sharp boundaries on the scope of the exemption model").

39134 S. Ct. 2751 (2014) [https://perma.cc/XLP9-4C2E].

40 See Andrew Koppelman \& Frederick M. Gedicks, Is Hobby Lobby Worse for Religious Liberty than Smith?, 9 U. ST. THOMAS J.L. \& PUB. POL'Y 223, 234 (2015) [https://perma.cc/7W55-5DQT].

${ }^{41}$ LUPU \& TUTTLE, supra note 1, at 198.

42 The toughness is expertly anatomized in WINNIFRED FALLERS SULLIVAN, THE IMPOSSIBILITY OF RELIGIOUS FREEDOM (2005).

431 Kent GreEnawalt, ReLigion And the CONSTitution: FreE EXercise AND FAIRNESS 210 (2006).
} 
proposed resolutions of the various types of accommodation issues are intensely fact-specific. Greenawalt acknowledges concerns "that most administrators have neither the talent nor the time to scrutinize individual religious sentiments and that individuals may be less than candid or genuinely uncertain about what they believe." ${ }^{, 4}$

Judgments about compelling interest are likewise influenced by assessments of burdens on religion: "In reality, courts consider burden in light of government interest and government interest in light of burden, striking a kind of balance." ${ }^{45}$ This is a tricky business, and it may be beyond judges' competence to do it without smuggling in illegitimate preferences for familiar religious views. In Greenawalt's account, the intensely context-sensitive judgments that ground accommodation decisions are ultimately inarticulate: "A person who believes that multiple values bear on the resolution of major social and legal issues ... may feel confident about which features matter most and even about particular overall assessments, without being able to offer a set of abstract principles to demonstrate the correctness of his judgments." ${ }^{46}$ That saves courts from making expressly religious judgments. Greenawalt suggests that the practice of religious accommodation can work as a series of ad hoc judgments. ${ }^{47} \mathrm{He}$ seems ready to trust courts to make these judgments.

Lupu and Tuttle's preference for the legislature seems to derive, in part, from the greater opacity of the legislative process, where no rule is followed and decisions do not have to be accompanied by a reasoned opinion. Greenawalt thinks that courts can have the same redeeming opacity.

I cannot say with confidence that Lupu and Tuttle are wrong about judicial accommodation. I can say that the idea of individual accommodation has produced gains for individual liberty that were unlikely to occur in any other way - certainly not by individual acts of legislative grace or administrative discretion. Consider the application of the Religious

${ }^{44} I d$. at 206.

${ }^{45} I d$. at 202.

46 Id. at 7. This inarticulateness at the core is understandably a source of frustration for some of Greenawalt's readers. See, e.g., Steven D. Smith, Discourse in the Dusk: The Twilight of Religious Freedom?, 122 HARV. L. REV. 1869, 1871-72 (2009) (reviewing 2 KENT GREENAWALT, RELIGION AND THE CONSTITUTION: ESTABLISHMENT AND FAIRNESS (2008)) [https://perma.cc/36PD-YMJZ].

${ }^{47}$ He writes:

No single theory covers everything; multiple reasons typically support a practice and carry varying weights in different contexts. This reality applies to many particular issues about government concessions not to perform general duties. Once this is recognized, people should not expect matters to reduce to a single justification that clearly warrants some exemptions and does not warrant others ....

Kent Greenawalt, Exemptions: Necessary, Justified, OR Misguided? 49 (2016) [hereinafter EXEMPTIONS]. For further discussion of Greenawalt, see Andrew Koppelman, Kent Greenawalt, Defender of the Faith, 95 TEX. L. REV. (forthcoming 2017) (reviewing EXEMPTIONS). 
Land Use and Institutionalized Persons $\mathrm{Act}^{48}$ to prisons, where it generates the only prisoner claims that are treated with any respect by the courts. ${ }^{49}$ Absent a discourse of religious liberty, it is hard to see how one could smuggle into American law the notion that convicts are human beings with rights. ${ }^{50}$ The benefits of the experiment seem to me to be reasons not to give up yet.

Their doubts about the regime have another implication. They provide some reason to wonder about proposals to expand the scope of accommodation even further-beyond religion to "conscience," or "moral liberty," or something even broader.

Christopher L. Eisgruber and Lawrence G. Sager offer an exemplary formulation of the objection to the privileging of religion: "religion does not exhaust the commitments and passions that move human beings in deep and valuable ways." religiously inspired concerns of minority religious believers with the same regard as that enjoyed by the deep concerns of citizens generally." ${ }^{2}$

But "deep" is not an administrable legal category. It is too vague for that. Even if we know what we mean, we cannot always know it when we see it. We are too opaque to one another, our depths are too personal and idiosyncratic, for the state to know for certain which commitments and passions really merit respect. ${ }^{53}$ That is why, Lupu and Tuttle observe, reasoning by analogy between religious and nonreligious accommodations, as Eisgruber and Sager propose, will not work. ${ }^{54}$

This is the most fundamental reason for protecting religious liberty indirectly, under the description of more general rights (so that heresy, for example, is protected as free speech). If there are going to be individual accommodations, however, then they must be under some description, and it is not clear that there is any good substitute here for "religion." ${ }^{55}$ Even if

\footnotetext{
48 Religious Land Use and Institutionalized Persons Act of 2000 (RLUIPA), 42 U.S.C. $\S \S 2000 \mathrm{cc}-$ 2000cc-5 (2006) [https://perma.cc/TU7F-7GQ7].

49 See David M. Shapiro, Lenient in Theory, Dumb in Fact: Prison, Speech, and Scrutiny, 84 GEO. WASH. L. REV. 972, 980 (2016) (finding RLUIPA "at least moderately successful in improving protection of prisoners' religious access rights") [https://perma.cc/2YS4-GY9N].

50 This is particularly important given American law's tendency to over-punish. See Joshua Kleinfeld, Two Cultures of Punishment, 68 STAN. L. REV. 933 (2016) [https://perma.cc/JL7K-W7SM].

${ }^{51}$ Christopher L. Eisgruber \& Lawrence G. Sager, The Vulnerability of Conscience: The Constitutional Basis for Protecting Religious Conduct, 61 U. CHI. L. REv. 1245, 1245 n. $\dagger \dagger$ (1994) [hereinafter Vulnerability of Conscience] [https://perma.cc/2ELE-PAGB]. They use "deep" repeatedly to describe the claims that should be treated equally with religious ones. CHRISTOPHER L. EISGRUBER \& LAWRENCE G. SAger, Religious FreEdom AND the CONSTITUtion 87, 89, 95, 101, 197, 241, 246, 252 (2007).

52 Eisgruber \& Sager, Vulnerability of Conscience, supra note 51, at 1285.

${ }^{53}$ Michael Sandel is right that liberalism presupposes this opacity. See Michael J. SAndel, LIBERALISM AND THE LIMITS OF JUSTICE 172 (2d ed. 1998).

${ }^{54}$ LUPU \& TUTTLE, supra note 1 , at 209.

55 See James W. Nickel, Who Needs Freedom of Religion?, 76 U. COLO. L. REV. 941, 958 (2005). Nickel is less cautious than Lupu and Tuttle on this question. He argues that individual exemptions can be created without using the category of "religion," for example when it is decided "to give scientific
} 
what we want to protect is deep and valuable concerns, the law needs workable proxies for this, and religion will almost certainly turn out to be one of these.${ }^{56}$ It is hard enough to determine when "religion" is present and triggers heightened scrutiny. How do you plumb the depths of "deep"?

The desire to dispense with "religion" and instead accommodate all deep and valuable human concerns, to create a world in which these are the basis for a pervasive practice of exemptions from generally applicable laws, is reminiscent of Herbert Marcuse's suggestion in Eros and Civilization that we should seek to abolish "surplus-repression," repression that exceeds the needs of civilization. ${ }^{57}$ Marcuse was thinking of sexual repression, and the ideal of sexual liberation that he articulated in 1955 has rocked our world. Parity for all deep and valuable concerns is an even more radical ambition. Anyone who proposes it as a rule of law needs to reflect on the implications of Lupu and Tuttle's arguments. We are still learning whether we can sustain any rule of accommodations from general laws.

researchers exemptions from drug laws in order to allow them to study controlled substances." Id. It is not obvious, however, and Nickel does not explain, how one could justify classic religious accommodations, such as the exemption of Jews from testifying on Saturdays, under a nonreligious description.

56 I have expanded on this point before. Andrew Koppelman, "Religion" as a Bundle of Legal Proxies: Reply to Micah Schwartzman, 51 SAN DIEGO L. REV. 1079 (2014) [https://perma.cc/7XUJBAKE]; Andrew Koppelman, Religion's Specialized Specialness, 79 U. CHI. L. REV. DiALOGUE 71 (2013) [https://perma.cc/JBY5-KZEP]; Andrew Koppelman, Nonexistent \& Irreplaceable: Keep the Religion in Religious Freedom, COMMONwEAL MAG. (Mar. 27, 2015, 12:00 PM), https://www.commonwealmagazine.org/nonexistent-irreplaceable.

${ }^{57}$ Herbert Marcuse, ERos AND CivilizATION: A PHILOSOPHICAL INQUiRY INTO FREUd (2d ed. 1966). 